\title{
The risk to cultural identity - Narrative of Mrs Takurine Mahesh Singh (1872-1959)
}

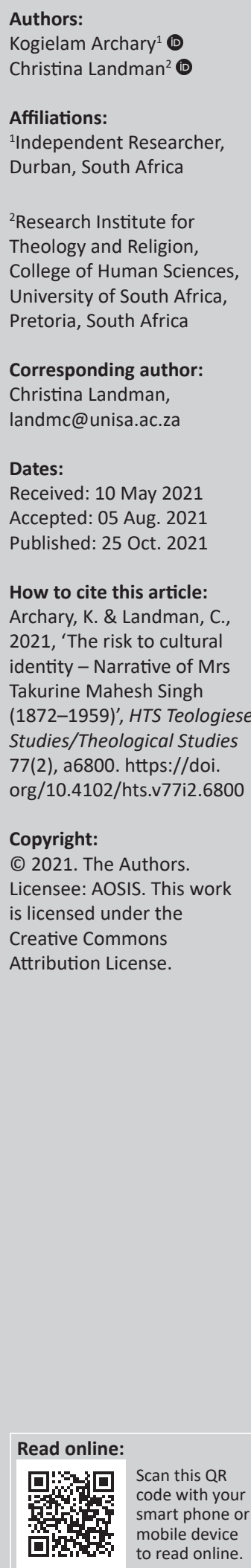

The article purports to examine the risk to cultural identity amongst an Indian community in South Africa using a single case study methodology. A case study approach was followed, using the qualitative research methodology, whereby not only the how (observation), but also adding focus on the thoughts, feelings, perceptions, experiences and motivations that people have underlie their behaviour. The year 1960 marked the 100th anniversary of the arrival of the Indians to the Colony of Natal, hence the study considers the period 1895 to 1960. Identifying with a particular culture allows members of that community to experience feelings of belonging and security. Moving across continents, Indian indentured sugar plantation labourers came to the Colony of Natal from 1860 until 1911 bringing with them their cultural identity. The risk to cultural identity is a significant contributor to an individual's well-being. Cultural identity may be viewed as a sense of belonging based on one's ancestry, rituals, religion, traditions, values and even language. When they were transported during the concurrent time of colonisation and indenture, they became displaced and thus an emotional threat to their well-being, belonging and security was created and simultaneously experienced. This threat compromised their cultural identity. This risk to cultural identity is investigated in the narrative of an Indian female national matriarch, Mrs Takurine Mahesh Singh who arrived in the Colony in 1895 and passed away in 1959. A risk to cultural identity existed, but the Indian community in South Africa did not experience deculturalisation. They were able to practise their ancestral culture without losing their identity. This is one of the findings and it concludes the abstract.

Contribution: The study of identity, identity diffusion, identity loss is a very important aspect to study, especially for displaced communities who suffer not only alienation from their mother country, but also losing contact and cultures as a result of displacement. This article provides insight on the risk to cultural identity in Natal between 1895 and 1960. In terms of the findings, cultural identity is an important contributor to well-being. Identifying with a particular culture gave the matriarch a feeling of belonging and security. It also provides access to social and other networks which provide support and shared strength, values and aspirations. Although a product of oral history, for this research, the article could not be supported by other historical materials in an attempt at balancing the views as scholars have not explored the widowed Indian nationals who have remained in the Colony after indenture. This article should not be viewed simplistically as a retelling of Mrs Singh's life story, but rather a narrative based on reflective memories that pieced together her departure from India under the political system of indenture, living and surviving as a widow under harsh laws and having multiple identities. The narrative oral history approach combined with a qualitative research methodology does not focus on analysis and interpretation but rather brings to the fore, the opportunity for further exploratory studies where the question 'why' will be answered.

Keywords: cultural identity; Takurine Mahesh Singh; Colony of Natal; South African Indians; indenture.

\section{Part One: Introduction}

\section{Aim}

This article explores the experiences of North Indian born Mrs Takurine Mahesh Singh (1872-1959) who arrived in the Colony of Natal as a 24-year-old. The aim of this article is to highlight - by exploring the narrative on Mrs Singh - the risk to cultural identity between 1895 and 1960 amongst Indian female nationals in South Africa.

Note: Special Collection: Social Memory Studies, sub-edited by Christina Landman (University of South Africa) and Sekgothe Mokgoatšana (University of Limpopo). 


\section{Reason for the study}

In 2020, South African Indians commemorated the 160th anniversary of the arrival of the Indian nationals to the Colony of Natal. Against this backdrop, the primary reason for this study is to research the risk to cultural identity as it pertains in particular to the Indian female nationals who were transported out of India by the British and onto African soil. With this move, there was some sort of creation or transformation of the human environment. The case of Mrs Singh encapsulates that cultural transformation of her existence in the new country.

\section{Limitations of this study}

This article does make an ambitious claim to study cultural identity spanning just under two centuries marked by different historical periods in the lives of an Indian community in South Africa from enslavement through an indenture system, life under the Union of South Africa through to South Africa's break from the British Commonwealth of Nations concluding the period under apartheid. Agreeably, this poses several challenges as:

- The period is too wide to cover in a short article as this one.

- The discussion provided is devoid of the South African or world history.

However, it must be noted that the matriarch was born in 1872 and passed away in 1959. She was born during the period of indenture, 12 years after the first shipload of Indian nationals landed in the Colony of Natal, colonised by Britain. India was also colonised by Britain. As sugar cane plantations flourished in Natal, there was a need for cheap labour which was found in India. Therefore, the Indians were brought to Natal. The matriarch outlived the official period of indenture which terminated in 1911, as India abolished this political system. In 1908 she was widowed; she took care of her two Natal born children and carried on living as a breadwinner in Natal. Further search on accounts of world and South African history, even though they are not discussed here because of the scope of this article, will yield a clearer historiography. The abridged literature review information provides a platform which indicates that cultural identity and the Indian community in South Africa have roots spanning just under two centuries which are marked by different historical periods from enslavement through an indenture system, life under the Union of South Africa through to South Africa's break from the British Commonwealth of Nations concluding the period under apartheid. The narrative of the matriarch is presented as part of cultural identity within a life changing historical journey and not just a life in isolation as her life experiences intertwined with and was dissected to include many identities where she was forced to negotiate her way in the intersection between society and self. Upon her death at age 87 , her remaining descendants in South Africa were able to become free citizens of a democratic country. The family represented by nonagenarian respondent Mr J S Singh, her grandson, an organic intellectual and retired school principal, had the opportunity to be a significant part of this research article on cultural identity. He provided reflective memories of his grandmother, while he was lucid, of good health and of clear thought at age 90 .

\section{Literary review}

In 1843, Natal became a British colony. Every effort was made to attract white settlers. By January 1852, success in perfecting the production of sugar cane was achieved; and this success brought more colonists into Natal. Recommendations were presented to the government that Indians be brought to Natal to work on the cane fields. There is available literature on Indian indenture (Bhana 1991; Desai \& Vahed 2010; Meer 1969; Mishra 2008; Tinker 1974). These authors have written extensively on different aspects of indenture, colonisation, culture and South African Indians. It is generally accepted that culture manifests itself in communication using signs or symbols, whether in language, music or other forms of expression. The Indian nationals brought with them signs or symbols, such as 'Namaste', reflected as two hands, facing each other and clasping each other, which is a nationally accepted form of greeting of India. Currently, descendants still use this form of greeting during gatherings of a traditional, cultural or religious nature as well as mainly when speaking to the elders in the Indian community. However, the literature review revealed that there is a severe lack of information, documentation and academic research on the theme of cultural identity amongst Indian female nationals in South Africa. As there are no academic works on this aspect available, this article - as South African Indians reflect on their heritage of 160 years in the country of their birth - is an attempt at starting to answer some of the questions regarding information on the topic of risk to cultural identity by reflecting on the narrative of Indian born matriarch, Mrs Takurine Mahesh Singh.

Literature referred is not discussed in depth as the oral history interview provided original information and the reflective memories were captured and presented unmediated without interpretation. By merely pointing to the literature, the intention is to leave the reader with the vantage point of knowing where to commence reading in terms of further personal research. In terms of the literature examined and what gaps exist, it may be stated that case studies of widowed Indian female nationals who came to the Colony on indenture could not be found. This study hopes to encourage research on the gaps that exist in terms of experiences that widowed women living during indenture endured with a focus on risk to cultural identity. What has emerged from this qualitative research is that many personal identities were necessary in order to survive as the racial divide was in place. But through the political systems, acculturation emerged and this allowed the Indian community in South Africa to remain behind and not necessarily return to India when their period of indenture was over. 


\section{Methodology}

A single unit can comprise of an individual, a group or an organisation. The goal of case studies is to describe, in greater detail, and generate an in-depth understanding of the case. A case study can be incremental in theory development. Using qualitative research methodology, this research was undertaken with an emphasis on descriptive analysis. The research design employed included a literature review, followed by a semi-structured qualitative research survey involving individual interviews. All ethical principles regarding the participant during the pilot and other interviews were followed. Other data collection instruments included documents and general deliberations - during pre- and postmeetings of the 1860 Indentured Labourers Foundation Verulam - and other non-published articles and notes.

An oral history interview coupled with written communication with responses from the respondent, Mr Jaisingh Surujbullee Singh (b 15 September 1930) was utilised for this article. Conversation with second generation, Mr Singh about his paternal grandmother, Mrs T M Singh began in 2018. Despite him being 87 at the time, he was able to share vivid memories and related life episodes from the indenture and postindenture period. Even though Mrs T M Singh arrived in the Colony of Natal (henceforth Natal) with her Indian culture and traditions, she had to adjust, adopt and accept the British culture and African lived experiences imposed upon her in her new home. Mr Singh was able to share much information regarding the cultural identity that was the status quo amongst the early Indian nationals. His long-term memory was astonishing and amazing as he was able to relay incidents with clarity and description as they occurred. The initial interview on 07 February 2018 was conducted at his Verulam home. The narrative of Mrs Singh was consequently further detailed on 03 November 2020 with face-to-face interviews again at his home. Thereafter, a telephonic interview with him took place on 15 January 2021.

The case study methodology was used as case studies provide opportunities for greater in-depth investigations of a single person, group, event or community. Typically, data is gathered by using methods such as oral history interviews and written correspondence. The research population for this article is restricted to the narrative of $\mathrm{Mr}$ Singh as he is the only nonagenarian of the 1860 Indentured Labourers Foundation Verulam. For the purposes of this article, a semi - structured questionnaire was utilised. The interview was not tape recorded as the respondent was satisfied with answering questions and the interviewing author (AKK) writing them down.

The single case study adopted in this article builds naturally into the subfield of (auto)biography, (inter)subjectivity and study of selves. However, for the period under review, the literature review does not indicate research that focusses on Indian female nationals that left India between 1860 and 1900, became widowed at an early age and consequently survived on their own terms. Therefore, no reference is made of such studies or methods of biographical writing.

\section{Explanation of terms}

'Cultural identity' Cultural identity is an important contributor to well-being. Identifying with a particular culture gives people feelings of belonging and security. It also provides access to social networks which provide support and shared values and aspirations. Migrants experience stresses that can impact their mental wellbeing, including the loss of cultural norms, religious customs, social support systems, adjustment to a new culture and changes in identity and concept of self (Usborne \& Taylor 2010).

'Acculturation' This refers to behavioural or psychological changes in immigrants (or their descendants) that follow migration. They are typically changes that make behaviour or ways of thinking more like members of the adopted society. Immigrants do not adequately acculturate, at least at certain levels of immigration. Acculturation is common, but generational (Berry 2005).

'Deculturalisation' Deculturalisation is the process by which an ethnic group is forced to abandon its language, culture and customs reference. It is the destruction of the culture of a dominated group and its replacement by the culture of the dominating group (Spring 2016). This has however, not happened to the local South African Indian community.

'Immigrant identities' These are negotiated in the intersection between society and self. Deviations provide insights into how and where individuals find belonging when not being mainstream (Ngo 2008).

\section{Interpretation of results}

Indian nationals who lived under colonial rule continued to practise their oral traditions and religious habits. These are practised by their descendants too. In this study, the reflective memories of the respondent were captured. In terms of the interpretation of the results, a non-interpretative, thematic approach has been used (Mestry \& Singh 2007). This methodological revolution has made way for a more interpretative approach because aspects of human values, culture and relationships are not described fully using quantitative research methods. Unlike quantitative researchers who seek causal determination, prediction and generalisation of findings, qualitative researchers allow for the phenomenon of interest to unfold naturally (Patton 2001). The respondent provided his reflections on his grandmother's life, and the authors recorded them in this article unmediated, that is, not analysing, mediating or interpreting them. These unmediated reflections are however, organised under three principal themes captured as: (1) colonisation, (2) indenture and (3) risk to cultural identity.

Deculturalisation, as a concept stemming from cultural risk, however, is not critically discussed in this paper as the Indian nationals and subsequent descendants were not 
forced to abandon their language, culture nor their customs. The Indian nationals were able to maintain significant aspects of Indian culture even though there was a risk to their cultural identity in Natal. In terms of the sub-themes, Arriving in the Colony, Ancestral ownership: Recounting memories; Culture: Indian traditional dress; Cultural identity: The prayer room; Indian-British-African identities; Switching between modes of judgement; Immigrant identity: Intersection between society and self; Acculturation: Behavioural or psychological changes in immigrants; Ancestral material loss: Earthly possessions; Reciting from the Ramayan; Women and traditional duties and finally The South African Indian community, are included in the presentation.

\section{Structure of the article}

The article follows a simple structure. Part One is the introduction which provides the aim of the article and the methodology used to reach that aim. Part Two is a second shorter part which gives the background to the history, or rather herstory, of Mrs T M Singh, who arrived in the Colony in 1895 and passed away in 1959.

Part Three is the main body of the article and contains the unmediated reflections of the respondent, which are arranged thematically. These themes were identified from the interview in terms of the respondent's reflective memories.

This oral history research has made it possible for the author to investigate a personal case of a widowed matriarch, born in India but indentured in Africa by the British. As the Indian nationals travelled across the oceans and moved from the passage of sea travel to the plantation as their place of living, they became exposed to new and different experiences. The article closes with a conclusion containing a summary of the research results.

\section{Part Two: Background to the history of Mrs T M Singh}

Mrs Singh did not return to India after her term of indenture was over. She chose to remain in Natal, and worked amongst the locals and lived under British rule while concurrently surviving under indenture conditions. During the period 1895 (arrival in Natal) to 1959 (date of death), she came to a new country but brought her ancestral culture and traditions with her. As she settled into life in Natal, she acknowledged the need to change aspects of her culture as the living and working conditions here were vastly different from India, the land of her birth. As an Indian national on African soil, she had to adapt, adjust and adopt to different ways of doing things. What may have been simple in India, now posed a challenge. However, the survival culture kicked in and later generation descendants now live as truly South Africans but still have a cultural link with India as their ancestral heritage provides a vaulting table for their understanding of self and society. Aspects of dress, food, music, dance, religious understanding, child rearing, rituals, traditions, festivals, prayer, values and more are maintained with the heritage culture.

During the changing stages of life - birth, puberty, marriage and death, heritage culture comes into play, providing guidance on what should be performed. Mrs Singh's story acknowledges that deculturalisation has not taken place despite colonisation, indenture, apartheid and democracy. The risk to cultural identity was averted because of noninvasive deculturalisation, even though acculturalisation, and immigrant identity status have occurred during the period 1895 to 1960. Organic intellectual Mr J S Singh, grandson of Mrs T M Singh, was interviewed for this article. $\mathrm{He}$ is the primary respondent as he was 29 years of age at the passing of his grandmother. Mrs T M Singh was a mother of two children. Her eldest child was Surujballee Mahesh who is the father of the respondent, Mr J S Singh. Her daughter, Chanderpathee died at the age of 35 . Not much else is known about her parents, siblings or other family members.

\section{Part Three: The narrative of Indian born indentured labourer Mrs Singh}

Mrs Singh's life experiences are chronicled to address the issues of cultural identity during her life under indenture.

\section{My paternal grandmother arriving in Natal}

Mrs Singh, according to the respondent who was interviewed on 07 February 2018:

$[A]$ rrived on the sailing ship Pongola XIX as an indentured labourer to work on the sugar plantations. It could be postulated that she arrived here seeking greener pastures in this foreign land. There are no records to indicate whether she came with her parents, other family members or friends.

However, from word of mouth and through the telling and retelling of the family stories, it has been established by Mr J S Singh (pers. comm., 07 February 2018) that:

$[M] y$ grandmother was employed as a labourer on a sugar farm owned by Michael A. La Lucia, known as Muckleneneuk Sugar in Mt. Moreland. Mt Moreland is almost north-east of Verulam which is a small Burrough on the North Coast of KwaZulu-Natal.

\section{My paternal grandfather, Mr Mahesh Jawahir Singh, Indenture number $\mathbf{5 8 5 7 5}$}

From the respondent's available records and personal collection, it is indicated that 'Number 58575 is the Indenture Number of Mr Mahesh Jawahir Singh. He came from Raipur, Purwa Jagapur, Sultanpur, India' (J.S. Singh, pers. comm., 07 February 2018). For many, success means reaching a goal, accomplishing a task, or otherwise accomplishing what they set out to do. To premise that the Singhs' were eventually successful is acceptable as not only was the matriarch able to maintain her children after the death of her husband, but she was also able to look after her grandchildren. According to the respondent: 'When my father's sister passed away at the age of 35, my grandmother took care of her daughter's five children' (J.S. Singh, pers. comm., 07 February 2018). 


\section{Family home after indenture}

By 1910 , nearly $26.85 \%$ of indentured men returned to India, but most chose to remain and they constituted the forbearers of the majority of present-day local Indians. The respondent mentioned that:

$[A]$ fter five years of indenture my grandparents still lived in a hut in Mt Moreland. Not much is known about the size of the hut, the number of rooms, the layout of the hut nor the furnishings. (J.S. Singh, pers. comm., 15 January 2021)

The supposition is that it would have been similar to other homes/huts in the area. It was the norm and culturally accepted that you would build according to your financial ability from the money that was saved working under the indentured system. According to the respondent:

$[M] y$ grandparents bought a piece of land described as Lot 206 c: 2 Ireland Street, Verulam. This property was bounded by white families. These white families comprised the resident priests of the Methodist Church and Anglican Church and Mr Henry Francis, a land and estate agent. The property was bought around 1900. My grandfather died at the age of 38 in the year 1908. (J.S. Singh, pers. comm., 07 February 2018)

\section{Ancestral ownership: Recounting memories}

On many occasions, the interviewing author visited Mr Singh on the ancestral family property as he still resides there with one of his three sons. It is on this property that he has revealed other stories about his past especially recounting memories of time spent there as a young boy. Upon enquiry of the family property, Mr Singh shared:

[T]he family home still stands on the same property and my grandmother's surviving four grandchildren were born there at 2 Ireland Street, Verulam, including myself. (J.S. Singh, pers. comm., 07 February 2018)

Mr Singh volunteered:

[A]fter my grandfather's death, my grandmother also occupied the adjoining property Lot 206 (Verulam Township) on a monthly tenancy to do vegetable gardening up to 1950 when the property was sold to Henry Francis, a white member of the Verulam Town Board. (J.S. Singh, pers. comm., 07 February 2018)

Her matriarchal role was extended to include nurturing, religious and economic care for her grandchildren. Being in Natal meant her responsibilities and actions were in keeping with the localised status quo, a change from the culture that was prevalent in India. The resultant shift in thinking and behaviour meant a different persona was evolving, a persona that included accultural and immigrant identity. The matriarch, in her wisdom, was able to able to do this - pass on ancestral culture from one generation to the next. The property she purchased in 1900, remains in the hands of her 90-year- old grandson, as of April 2021. This ancestral ownership allowed the respondent to be proud of his family heritage and confidently share details of the matriarch.

\section{Culture: Indian traditional dress}

Culture in any of its meaning is the property of a human group (Godwin \& Gittel 2021:313). The anthropological definition of culture includes that everything performed by human beings falls under the classification of culture According to Mr Singh:

$[M] y$ grandmother dressed in her traditional gear, the 7 metre white sari when she became widowed. She wore the sari for the entire day, whether she worked on the fields, in her own garden or in her home. During her married life, to identify herself as a married woman, she dotted her forehead with Sindoor. This orange powder was also placed in the path created by the separation of her hair from the middle of her forehead to her crown. (J.S. Singh, pers. comm., 03 November 2020)

This was the culture in India, and it is something that the Indian nationals in Natal did not compromise with in their new country. Even though it is 160 years since the Indians arrived in South Africa, Indian women still wear their 'sarees' but have moderated its use to mainly ceremonial or cultural events. Married women still apply the vermillion powder referred to as 'tikka' on their forehead, but these are now in ink form, plastic, material, patterned, shaped, colourful, bling etc. Certain aspects of Indian culture have withstood the test of time. On the contrary, her husband may have worn the 'dhoti' and 'turban', but this garb has but almost disappeared in South Africa. The 'dhotis' used by Hindu men is between $1.5 \mathrm{~m}$ and $3 \mathrm{~m}$ in length and tied and tucked around the waist, so that it does not fall off. The 'turban' is headgear used mainly by Hindu men. 'Turbans' are now mainly used by priests and bridegrooms on their wedding day. The 'dhoti' is only worn by priests at traditional functions, prayer festivals or in religious contexts.

\section{Cultural identity: The prayer room}

Knowing oneself and experiencing oneself as clearly defined has been linked to positive self-esteem and psychological well-being (Usborne \& Taylor 2010). Cultural identity is an important contributor to people's well-being. Identifying with a particular culture gives people feelings of belonging and security. Maintaining aspects of their Indian culture provided the Singhs' with a sense of belonging and security within the localised Indian community. Localised Indian families perhaps engaged in similar activities in their own homes at different times and opportunities. According to the respondent, "The pride of the house was her prayer room. She slept in this room as well' (J.S. Singh, pers. comm., 07 February 2018). This activity perhaps occurred as it seemed most natural to Mrs Singh; as this was where she was comfortable and probably most herself, an Indian national in an African country surviving during colonialism. Her prayer room showcased aspects of her Indian cultural identity such as her lamp, brass containers, incense sticks, matches, wicks, camphor, ghee (clarified butter), pictures of deities, religious scriptures, etc. In her home, she prayed and performed traditional rituals according to African time as India is three and a half hours ahead. She maintained aspects of her cultural 
identity but there were modifications of what she did, where it was performed, how and when it took place.

\section{Immigrant identity: Intersection between society and self}

Exemplified by the discourse of culture clash or of immigrants being torn between two worlds, this prevalent understanding structures the experiences, cultures and identities of immigrants as unchanging and fixed in time (Ngo 2008:4-11). The immigrant identity is negotiated in the intersection between society and self. Deviations provides insights into how and where individuals find belonging when not being mainstream. With the death of the patriarchal breadwinner, the matriarch had to negotiate a new identity for herself and her family. The new immigrant identity that she adopted challenged Mrs Singh as she then had to make decisions regarding family issues such as food, shelter and clothing. According to Mr Singh:

$[M] y$ grandmother continued to complete the house she and her late husband had started to build in 2 Ireland Street, Verulam. It is in this house that her children and grandchildren learnt from her the art of living and the tenacity to ensure survival. (J.S. Singh, pers. comm., 07 February 2018)

Her immigrant status forced her to think and act beyond Indian cultural lines.

According to the respondent:

$[H]$ er only daughter Chanderpathee died in 1935, following childbirth complications and my grandmother was now faced with caring for her 5 grandchildren. (J.S. Singh, pers. comm., 07 February 2018)

Her immigrant identity forced her to take on this innovative grand-mothering role as she basically had to perform all duties associated with her grandchildren. In Natal, she found herself challenged as the concept of intersection between society and self was promulgated to the fore with the death of her daughter. She had a different persona in Natal, a new self; a novel identity that now faced society through renewed cultural lenses. She had to adjust to caring for young children at an advanced age. Her immigrant identity made that possible as pastoral care for the children was needed and who better than a maternal grandmother to provide that care, and simultaneously ensure that traditions, values, norms, cultural issues, religious teachings and more is objectified in the intersection between society and self.

\section{Ancestral material loss: Earthly possessions}

After long hours under the hot sun a paltry sum of money was saved, and this was used to purchase absolute necessities. All possessions were highly treasured. According to the respondent:

$[U]$ nfortunately, my grandmother lost all their earthly possessions when the Umdloti River came down in flood. Verulam was located along the banks of the Umdloti River. Fortunately, she managed to save her holy Ramayan. (J.S. Singh, pers. comm., 07 February 2018)
'The Ramayan is the Hindu scripture that offers guidance in life' (J.S. Singh, pers. comm., 03 November 2020). It is obvious that the teachings of the Ramayan created a firm belief system that ensured survival, and this mitigated the risk of total loss of culture and cultural identity.

\section{Women and traditional duties}

Mrs Singh assisted families in terms of cultural services and traditional duties. In terms of her heritage culture, Mr Singh shared that:

[M]y grandmother was not of a Brahman (priest) caste, and was not entitled to any remuneration for religious services rendered to a family. Women during this period were very conservative and did not challenge the role of religiously accepted male pundits (priests). Male priests only discussed family functions with male members of a family, who in turn made all decisions. Mrs Singh was thus most welcome in homes to discuss functions with female members of the family and take joint decisions with the males. (J.S. Singh, pers. comm., 07 February 2018, 15 January 2021)

The culture of patriarchy was also in place. Only males could engage in certain aspects of the Indian heritage culture. And this status quo was accepted by the localised community as patriarchy was entrenched globally, be it in the African homestead or the British home.

\section{South African Indian Descendants}

All indentured labourers were issued with indenture numbers. Mr Singh mentioned that:

[T] hese indenture numbers served as their identity document, passport and employee number. This number is used to discover your roots that have been captured on what is now referred to as the ship lists. I was able to get details of my maternal and paternal ancestries of the ship list. Both my ancestral families arrived in this country as indentured Indians. (J.S. Singh, pers. comm., 07 February 2018)

However, with hard work, sacrifice and determination, the Singh family was able to move from the bondage of indentured workers to other fields of work. In her new country, she engaged in some activities that were reminiscent of her birth country. She lived a tripartite existence: that of family survival under colonial regulations, work under indenture rules and life directed by Indian culture. Mr Singh ventured that: 'My grandmother was also well-known for her tasty, magnificent pickles which she stored in the prayer room' (J.S. Singh, pers. comm., 07 February 2018). A clear reference to her Indian culture pickles and the prayer room.

In Natal, education became key. According to Mr Singh, 'At the same time, as helping his mother with the farming activities, my father had a passion for learning'. The cultural perspective towards education amongst Indian people in South Africa changed over the previous decades as education was viewed as the gateway to a better life and a ticket to greener pastures. According to the respondent: 
[M]y father became self-educated and he rose in the academic field eventually retiring as a school principal. He was acknowledged as a legendary community leader while my mother, Mrs D Singh was a stay-at-home mother to five children. My parent's marriage took place in Umzinto on the 4th of May 1927. They had five children. My sisters are Thara Devi Maharaj (1928), Champawathee Singh (1932), Manorama Devi Somers (1934), and my late brother Ajith Kumar (1941) who passed away in 1962. (J.S. Singh, pers. comm., 07 February 2018)

Indian nationals in the Colony were bound by the cultural roots of their experience at point of departure from India and this departure which resulted in their arrival in Natal, provided a shared cultural experience during the period of indenture to post-indenture and post-apartheid. Even though Mrs Singh arrived on indenture, her descendants have followed in her footsteps of giving back to the community by choosing to serve in the noble profession of education as well as other fields, a clear indication of aspirations that did not fit well with the ethos of colonialism, but nonetheless occurred. Before her death, Mrs Singh knew that her grandchildren would be taken care of. Her son was employed in the education sector. The family survived despite difficulties.

\section{According to the respondent:}

[M]y grandmother passed away in 1959 at the age of 90 years. I began teaching in 1952. The North Local Council of eThekwini Municipality in KwaZulu-Natal in September 2000 named the road between the present BP Garage and the old cemetery in Verulam as Mahas Singh Road in honour of her. Her sense of service to the community has passed on to her fourth successive generation. (J.S. Singh, pers. comm., 07 February 2018).

\section{According to Mr Singh:}

\begin{abstract}
Amongst my siblings, three of us were involved in education and I eventually retired in 1991. Savithree Devi, my wife of 54 years and the mother of my three sons, Naresh Kumar, Bimal and Ujen, passed away in 2013, was also a pre-school teacher who had a great interest in music and was an exceptional singer. (J.S. Singh, pers. comm., 07 February 2018)
\end{abstract}

Mr Singh shared that his family is steeped in cultural value and the family has made many trips to India to experience this cultural value and empowerment.

$[B]$ oth my parents, Surujbullee and Daie Singh had the honour of meeting Swami Sivananda (Founder of Divine Life Society) in Rishikesh in 1962. Their trip to India was incredible. Going back to the birth country of their parents would have been a cultural experience as they were both first generation South Africans of Indian descent. (J.S. Singh, pers. comm., 07 February 2018)

The life of Mrs Singh may have been a difficult one but the cultural value she imparted to her children and which was later passed on to her grandchildren is evident as Mr Singh practises what he learnt under his grandmother's tutelage, and his habits have been observed by his descendants which form the basis of their life, living in South Africa, a democracy, so different from the indentured experience.

\section{Conclusion and recommendations}

This section addresses cultural identity as the main aspect of this article. The 'risk' to cultural identity of the Indian nationals who lived under colonial rule did exist, but did not take place physically as the Indian nationals continued to practise their oral traditions and religious habits. A risk to cultural identity existed, but the Indian community in South Africa did not experience deculturalisation as they were able to practise their ancestral culture without losing their identity. Communication with the motherland between 1895 and 1960 ensured that aspects of their cultural heritage were maintained. However, communications between people have been transformed in a variety of ways in recent years. The Internet, social media platforms, smart androids, etc. are methods that are used for current communication between communities, countries and continents. This is true for the descendants of indentured Indians as well. Much of what is written and disseminated currently about indenture and the commemoration of the indenture movements globally is performed via social media platforms, online or through digital technology. The changes in the manifestations of cultural practices have perhaps never been as extensive as in recent years. Even though this may be true on a global scale, Indians in South Africa still maintain aspects of their Indian roots and culture.

The descendants of Mrs Singh have certainly adopted to living in a multi-cultural society following a metropolitan international lifestyle, even though they may occasionally enjoy pickle, sing some religious songs or attend cultural functions dressed in Indian attire. Even though the Indian nationals lived under colonial rule, their descendants practised their oral traditions and religious habits. The Indian diaspora has made international inroads in all aspects of life. The tenacity to work diligently is demonstrated not only by the Indian nationals themselves, but the descendants of the indentured workers. The narrative of Mrs Singh sheds light on the difficult relationship between indentured life in a foreign country and the cultural conundrum that many Indian female nationals of that era experienced. There was a risk to cultural identity. However as deculturalisation did not take place with this community, aspects of their ancestral culture are still in place, post 160 years since the arrival of the Indian nationals to Natal. There was however a shift in Indian identity as they arrived as Indian nationals, experienced bonded slavery as indentured workers but their descendants now live as South African citizens, with the hybrid denotation of South African Indians.

\section{Acknowledgements Competing interests}

The authors declare that they have no financial or personal relationships that may have inappropriately influenced them in writing this article. 


\section{Authors' contributions}

Both authors contributed equally towards this article.

\section{Ethical considerations}

The respondent, Mr Singh, is the president of the 1860 Indentured Labourers Foundation Verulam and has over the past decades written extensively on the Indian labourers' experiences in South Africa. He was interviewed in his personal capacity, not in his official capacity as President of the 1860 Indentured Labourers Foundation Verulam. He was duly informed of the aims and objectives of this research article. He graciously consented as it was clearly stated that the information received would be for research and academic purposes. The respondent was comfortable and the main interview took place telephonically even though a major percentage of the information was written down after the respondent had answered questions from a research instrument. The respondent provided written consent and agreed to the contents of this article.

\section{Funding information}

This research received no specific grant from any funding agency in the public, commercial, or not-for-profit sectors.

\section{Data availability}

Data sharing is not applicable to this article, as no new data were created or analysed in this study.

\section{Disclaimer}

The views and opinions expressed in this article are those of the authors and do not necessarily reflect the official policy or position of any affiliated agency of the authors.

\section{References}

Berry, J.W., 2005, 'Acculturation', in W. Friedlmeier, P. Chakkarath \& B. Schwarz (eds.), Culture and human development: The importance of cross-cultural research for the social sciences, pp. 291-302, Psychology Press/Erlbaum, Taylor \& Francis, London.

Bhana, S., 1991, Indentured Indian Emigrants to Natal 1860-1902. A study based on ship lists, Promilla, New Delhi.

Desai, A. \& Vahed, G., 2010, Inside Indian indenture. A South African Story, 1860-1914, HSRC Press, Cape Town.

Godwin, M. \& Gittel, J.H., 2021, Sociology of organizations structures and relationships, Sage, Los Angeles, CA.

Maharaj, S.M., 1950, The diary of the late Pundit S.M. Maharaj, s.n., Verulam.

Meer, F., 1969, Portrait of Indian South Africans, Avon House, Durban.

Merriam, S.B., 1998, 'Qualitative research and case study applications in education. Revised and expanded from 'Case Study Research in Education', viewed 13 April 2021, from https://eric.ed.gov/?id=ED415771

Mestry, R. \& Singh, P., 2007, 'Continuing professional development for principals: A South African perspective', South African Journal of Education 27(3), 477-490.

Mishra, V., 2008, The literature of the Indian diaspora: Theorizing the diasporic imaginary, Routledge, New York, NY.

Ngo, B., 2008, 'Beyond "Culture Clash" understandings of immigrant experiences', Theory into Practice 47(1), 4-11. https://doi.org/10.1080/00405840701764656

Singh, J.S., 2018, Tell your mother's story, vol. 1, ZY Printers, Durban.

Spring, J., 2016, Deculturalization and the struggle for equality: A brief history of the education of dominated cultures in the United States, Imprint Routledge, New York, NY.

Patton, M.Q., 2001, Qualitative research and evaluation methods, 2nd edn., Sage Publications, Thousand Oaks, CA.

Streubert, H.J. \& Carpenter, D.R., 1999, Qualitative research in nursing: Advancing the humanistic imperative, 3rd edn., Lippincott Williams \& Wilkins, Philadelphia, PA.

Tinker, H., 1974, A new system of slavery: The export of Indian labour overseas, 1830-1920, Oxford University Press, New York, NY.

Usborne, E. \& Taylor, D.M., 2010, 'The role of cultural identity clarity for self-concept clarity, self-Esteem, and subjective well-being', Personality and Social Psychology Bulletin 36(7), 883-897. https://doi.org/10.1177/0146167210372215 